\title{
Desain Sistem Informasi Manajemen Pariwisata Sulawesi Utara sebagai wadah website Dinas Pariwisata
}

\author{
Yonatan Parassa ${ }^{a}$, Mex U Pesik ${ }^{b^{*}}$, Toban Tiku Pairunanc*, Alma K. \\ Pongtuluran ${ }^{\text {* }}$
}

\author{
aJurusan Elektro/Prodi Teknik Listrik, Politeknik Negeri Manado \\ bJurusan Pariwisata/Prodi Ekowisata Bawah Laut, Politeknik Negeri Manado \\ cJurusan Elektro/Prodi Teknik Informatika, Politeknik Negeri Manado
}

KATA KUNCI

Desain Sistem

Pariwisata Sulawesi Utara

Wadah website

Dinas Pariwisata

\begin{abstract}
A B S T R A K
Penyampaian informasi melalui media internet merupakan kebutuhan dalam era digital saat ini. Website merupakan salah satu perangkat diinternet untuk menyampaikan informasi baik oleh pemerintah maupun swasta ataupun perorangan. Sangat disayangkan di Provinsi Sulawesi Utara baru 3 Dinas dari 16 Dinas Pariwisata yang memiliki website. Tujuan penelitian ini adalah melakukan desain sistem berbasis web yang digunakan sebagai wadah bagi dinas pariwisata di lingkungan provinsi sulawesi utara, mengingat dari 16 dinas pariwisata hanya 3 dinas pariwisata yang memiliki Website.

Metode yang digunakan untuk membangun penelitian ini menggunakan metode "waterfall". Hasil penelitian ini adalah Desain sistem Pariwisata sulawesi utara sebagai wadah website Dinas Pariwisata menggunakan metode pengembangan sistem "waterfall".

A B S T R A C T

Submission of information through internet media is a necessity in the current digital era. Website is one of the internet tools to convey information either by the government or private or individuals. It is unfortunate that in North Sulawesi Province only 3 of 16 Tourism Offices have websites. The purpose of this study is to design a web-based system that is used as a forum for tourism Offices in the province of North Sulawesi, given that of the 16 tourism only 3 tourism Offices have a Website.

The method used to build this research uses the "waterfall" method. The results of this study are the design of the North Sulawesi Tourism system as a website for the Office of Tourism using the "waterfall" system development method.
\end{abstract}

K E Y W O R D S

System Desaign

North Sulawesi Tourism website container tourism Office

TERSEDIA ONLINE

31 Okotober 2019

\section{Pendahuluan}

Sektor Pariwisata di Indonesia sebagai salah satu unggulan untuk mendatangkan devisa terus mengalami perkembangan, termasuk di Provinsi Sulawesi Utara. Kunjungan wisatawan di Provinsi Sulawesi Utara mengalami perkembangan yang sangat pesat dan mendapatkan penghargaan Rising Star pada bulan Juli 2019.

Berdasarkan data di Kemenpar dan BPS 2018, kunjungan wisatawan ke Sulut meningkat drastis dari tahun 2017 ke 2018. Untuk wisatawan mancanegara, kunjungan ke Sulut tahun 2017 mencapai 79.675. Jumlah ini meningkat drastis ke angka 122.101 tahun 2018. Peningkatan juga terjadi di wisatawan nusantara. Dari jumlah 2.767.320 kunjungan tahun 2017, melonjak ke angka 4.075.993 kunjungan tahun 2018 [1].

Teknologi berkembang sangat pesat, hampir semua bidang kehidupan. Teknologi komputer merambah hampir semua sektor terutama untuk pengolahan data [2]. Perkembangan teknologi informasi juga berdampak pada dunia pariwisata. Dimana promosi pariwisata juga dilakukan dengan 
menggunakan teknologi yaitu internet. Sektor pariwisata juga dipengaruhi oleh teknologi. Melakukan perjalanan wisata tidak lepas dari teknologi terutama internet [3].

Hasil penelitian UNWTO tahun 2017, sekitar 82 persen wisatawan lebih suka mencari langsung informasi mengenai suatu destinasi wisata melalui informasi digital [4]. Sebagian besar wisatawan mendapatkan informasi tentang objek wisata melalui media elektronik dan internet, selain melalui rekomendasi dari teman/keluarga/agen travel. Ketersebaran informasi akan mampu meningkatkan minat berkunjung dari para wisatawan baik domestik maupun mancanegara [5]. Sangat disayangkan Promosi dan Pengelolaan Pariwisata di Sulawesi Utara dengan teknologi informasi komunikasi (TIK) masih sangat minim. Menurut observasi Tim Penulis pada tahun 2018, Provinsi Sulawesi Utara yang memiliki 16 Dinas Pariwisata, dimana hampir semua dinas memprioritaskan melakukan promosi berbasis kertas. Hanya 3 Dinas yang memiliki website. Menurut Umami Z (2015), dalam Parassa (2018) Pusat informasi yang ditautkan ke media sosial sehingga bisa diakses oleh dunia pariwisata perlu diadakan oleh dinas pariwisata [6].

Tujuan dari penelitian ini adalah merancang sistem informasi yang merupakan wadah website dan database bagi Dinas Pariwisata di Provinsi Sulawesi Utara untuk menyampaikan informasi objek wisata, sosialisasi program kerja serta edukasi bahwa masyarakat dapat meningkatkan pendapatan melalui usaha wisata. Hasil dari penelitian ini adalah rancangan sistem informasi Manajemen Pariwisata Sulawesi Utara (SIMPASU) sebagai wadah website Dinas Pariwisata menggunakan metode waterfall yang dapat dijadikan rujukan untuk pengembangan sistem.

\section{Material dan Metode}

Sistem adalah suatu rangkaian yang terdiri dari dua atau lebih komponen yang saling berhubungan dan saling berinteraksi satu sama lain untuk mencapai tujuan dimana sistem biasanya terbagi dalam sub system yang lebih kecil yang mendukung system yang lebih besar [7].nkonsep sistem sebagai kumpulan elemen yang koheren [8].

Sutabri (2004) dalam Saraswati (2013), Sistem Informasi adalah suatu sistem didalam suatu organisasi yang mempertemukan kebutuhan pengolahan transaksi harian yang mendukung fungsi operasi organisasi yang bersifat manajerial dengan kegiatan strategi dari suatu organisasi untuk dapat menyediakan kepada pihak luar tertentu dengan laporanlaporan yang diperlukan [9].

A.Yoeti, Oka. (1996) dalam Parassa (2018) Pariwisata merupakan perjalanan dari satu daerah ke daerah lain secara sementara bukan untuk bekerja tetapi untuk keinginan lain [10]. waterfall secara umum terdiri dari 5 tahapan, yaitu analis, desain, implementasi, tersting dan perawatan [11].Waterfall adalah Metode pengembangan sistem yang digunakan dalam penelitian ini. Penggunaan metode waterfall karena sudah teruji dan banyak digunakan dalam pengembangan perangkat lunak.

Mudah dan murah merupakan alasan lain sehingga metode waterfall banyak digunakan [12].

\section{Hasil dan Pembahasan}

Perancangan sistem informasi Manajemen Pariwisata Sulawesi Utara (SIMPASU) sebagai wadah website Dinas Pariwisata menggunakan metode pengembangan sistem waterfall seperti pada gambar berikut [13].

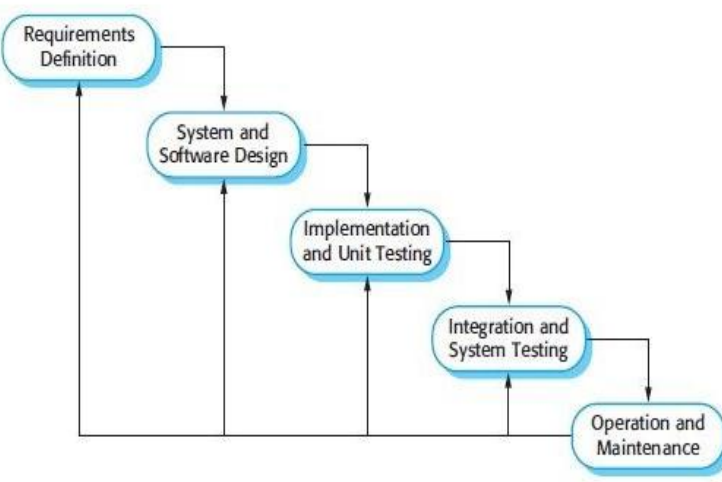

Gambar 1. Waterfall

Untuk menghasilkan rancangan dan sistem yang benar, harus disiplin menerapkan setiap tahapan pada metode pengembangan sistem waterfall.

Berikut setiap tahapan :

1. Requirements definition

Pada tahapan ini, ditetapkan tujuan SIMPASU dengan cara melakukan komunikasi dengan pihak terkait dalam hal ini dinas pariwisata, industri pariwisata dan pihak terkait lainnya. Pengumpulan data baik data primer dan sekunder menggunakan beberapa metode, yaitu observasi, wawancara, dokumentasi dan pustaka [14].

\section{System and software design}

Tahap system and software design adalah tahapan perancangan. Beberapa perangkat desain atau pemodelan sistem antara lain flowchart, entity relationalship diagram (ERD), konteks diagram, use case diagram, activity diagram ataupun perangkat lain. Penekanan pada tahapan ini adalah menggunakan perangkat pemodelan yang sudah teruji.

Tahap desain dapat menggunakan metode Enterprise Architecture dengan tahapan inisiasi perencanaan, pemodelan bisnis, sistem dan teknologi saat ini, arsitektur data, arsitektur aplikasi, arsitektur teknologi dan rencana implementasi.

\section{Implementation and unit testing}

Tahap Implementation and unit testing adalah tahapan dilakukan penulisan kode program baik untuk database maupun aplikasi. Tahap ini juga menguji unit SIMPASU.

\section{Integration and system testing}

Tahap integration and system testing adalah tahapan dimana unit-unit SIMPASU diintegrasikan dan melakukan pengujian sistem. Pengujian unit, integrasi dan sistem menggunakan metode black box yaitu menguji fungsi dan memastikan tujuan SIMPASU tercapai.

\section{Operation and Maintenance}


Tahap operation and maintenance adalah tahapan dimana perangkat lunak SIMPASU yang dihasilkan digunakan. Perawatan dilakukan guna lebih menjamin keberlangsungan penggunaan sistem.

\section{Kesimpulan}

Penelitian ini membahas tentang bagaimana merancang SIMPASU dengan menggunakan metode Waterfall didahului dengan menetapkan tujuan sistem, melakukan komunikasi dengan pihak terkait. Rancangan sistem dilakukan dengan beberapa perangkat pemodelan yang telah teruji. Penulisan kode program dan pengujian unit dan sistem dilakukan dengan disiplin mengikuti prosedur. Pengujian sistem dilakukan menggunakan metode black box dengan memperhatikan tujuan sistem sehingga dapat menghasilkan perangkat lunak yang sesuai dengan kebutuhan. Pengembangan sistem dapat dilakukan sesuai dengan kebutuhan. Penelitian ini dapat dijadikan rujukan untuk pengembangan sistem.

\section{Ucapan Terimakasih}

Dengan penuh kerendahan hati, Tim Penulis menghaturkan terimakasih yang sebesar-besarnya kepada Pemerintah Negara Republik Indonesia melalui Kementerian Riset Teknologi dan Pendidikan Tinggi yang telah mendanai penelitian ini melalui Direktorat Riset dan Pengabdian kepada Masyarakat. Tim Penulis juga menyampaikan terimakasih kepada Pimpinan Politeknik Negeri Manado dan seluruh Pihak terkait sehingga penelitian ini dapat terlaksana, Semoga Tuhan Senantiasi Menyertai dan Memberikati kita semua.

\section{Daftar Pustaka}

https://www.liputan6.com/lifestyle/read/4028740/ menpar-menilai-pembangunan-pariwisata-disulut-sangat-pesat. Diakses pada tanggal 05 Agustus 2019

Parassa, Y., Pesik, M. U., \& Bijang, N. L. (2018). Model Sistem Informasi Biaya Kunjungan Wisata di Provinsi Sulawesi Utara. JOURNAL OF APPLIED INFORMATICS AND COMPUTING, 2(2), 34-37

Kementerian Pariwisata. 2017. Rencana strategis 2018-2019.

http://eperformance.kemenpar.go.id/dokumen /3Buku\%2ORENSTRA\%202018-

2019_Revisi\%204_opt.pdf. Diakses pada tanggal 02 agustus 2019

https://www.gosumbar.com/berita/baca/2018/12/ 31/bukan-sekedar-stan-pameran-bagaimananasib-pariwisata-riau-2019. Diakses pada tanggal 02 Februari 2019

Mulyana, B. (2012). Pengembangan Kota Bogor Sebagai Destinasi Pariwisata Internasional. Jurnal IImiah Pariwisata. Vol. 2 (1): 109-222.]

Parassa, Y., Pesik, M. U., \& Bijang, N. L. (2018). Development of Website Model of North Sulawesi Province Tourist Attraction in Multi User. International Journal of Computer Applications, 975, 8887.

Romney, M. B., \& Steinbart, P. J. (2015). Accounting information systems. Pearson Education

Zarvić, N., \& Wieringa, R. (2014). An integrated enterprise architecture framework for businessIT alignment. Designing Enterprise Architecture Frameworks: Integrating Business Processes with IT Infrastructure, 63(9)

Saraswati, E. (2013). Sistem Informasi Akademik Berbasis Web Pada Sekolah Menengah Pertama Negeri 3 Pringkuku. IJNS-Indonesian Journal on Networking and Security, 2(4)

Parassa, Y., Bijang, N. L., \& Pesik, M. U. (2018, October). Online Tourism Architecture Design in North Sulawesi Province. In 2018 International Conference on Applied Science and Technology (iCAST) (pp. 536-539). IEEE

Bassil, Y. (2012). A simulation model for the waterfall software development life cycle. arXiv preprint arXiv:1205.6904

Adenowo, A. A., \& Adenowo, B. A. (2013). Software Engineering Methodologies: A Review of the Waterfall Model and Object-Oriented Approach. International Journal of Scientific \& Engineering Research, 4(7), 429

Sommerville, I. (2011). Software Engineering 9th Edition. Addison-Wesley

Gunawan, I. (2013). Metode penelitian kualitatif. Jakarta: Bumi Aksara 